Abstracta Iranica Abstracta Iranica

Revue bibliographique pour le domaine irano-aryen

Volume 29 | 2008

Comptes rendus des publications de 2006

\title{
"The Excavation of Hasanlu: An Archaeological Evaluation ». BASOR, 342, mai 2006, pp. 69-94.
}

\section{Astrid Nunn}

\section{(2) OpenEdition}

1 Journals

\section{Édition électronique}

URL : http://journals.openedition.org/abstractairanica/26212

DOI : 10.4000/abstractairanica.26212

ISSN : 1961-960X

Éditeur :

CNRS (UMR 7528 Mondes iraniens et indiens), Éditions de l'IFRI

\section{Édition imprimée}

Date de publication : 15 mai 2008

ISSN : 0240-8910

\section{Référence électronique}

Astrid Nunn, « «The Excavation of Hasanlu: An Archaeological Evaluation ». BASOR, 342, mai 2006, pp. 69-94. », Abstracta Iranica [En ligne], Volume 29 | 2008, document 85, mis en ligne le 15 septembre 2008, consulté le 26 septembre 2020. URL : http://journals.openedition.org/abstractairanica/26212 ; DOI : https://doi.org/10.4000/abstractairanica.26212

Ce document a été généré automatiquement le 26 septembre 2020.

Tous droits réservés 


\title{
« The Excavation of Hasanlu: An Archaeological Evaluation ». BASOR, 342, mai 2006, pp. 69-94.
}

\author{
Astrid Nunn
}

1 Le site de Hasanlu a été fouillé entre 1956 et 1974. Depuis 50 ans de nombreux articles ont paru mais un seul volume final a été publié (le niveau d'époque islamique). L'A. aimerait pallier cette insuffisance en présentant de manière aussi synthétique que critique notre savoir et nos lacunes sur cette fouille importante du nord-ouest de l'Iran. Il laisse de côté la nécropole, qui n'a jamais été publiée. L'A. présente Hasanlu par couche et débute par la plus ancienne VII A-C (Bronze Ancien). Il laisse en suspens la question non résolue de la fin de la couche VI ainsi que celle de la chronologie des couches V, IV et III. Ce choix est sage et ne donne que plus de valeur à ce bref résumé qui servira d'introduction ou, si l'on veut, d'article encyclopédique. D'ailleurs les plans n'ont pas été redessinés par l'A. mais sont ceux de la Mission américaine. Il donne parfois raison à l'un ou l'autre scientifique, mais toujours après avoir présenté la chronologie de l'argumentation archéologique. En conclusion il réitère ce que tous les archéologues savent: un site non publié est un site perdu. L'article se termine par une liste chronologique des publications les plus importantes sur Hasanlu.

\section{INDEX}

Thèmes : 3.2.2. Pré-Achéménides et Achéménides 
AUTEURS

ASTRID NUNN

Université de Munich 